\title{
Groundwater use for irrigation - a global inventory
}

\author{
S. Siebert ${ }^{1}$, J. Burke ${ }^{2}$, J. M. Faures ${ }^{2}$, K. Frenken ${ }^{2}$, J. Hoogeveen ${ }^{2}$, P. Döll ${ }^{3}$, and F. T. Portmann ${ }^{3}$ \\ ${ }^{1}$ Institute of Crop Science and Resource Conservation, University of Bonn, Bonn, Germany \\ ${ }^{2}$ Food and Agriculture Organization of the United Nations, Rome, Italy \\ ${ }^{3}$ Institute of Physical Geography, Goethe University Frankfurt, Frankfurt am Main, Germany \\ Received: 10 June 2010 - Published in Hydrol. Earth Syst. Sci. Discuss.: 28 June 2010 \\ Revised: 28 September 2010 - Accepted: 30 September 2010 - Published: 12 October 2010
}

\begin{abstract}
Irrigation is the most important water use sector accounting for about $70 \%$ of the global freshwater withdrawals and $90 \%$ of consumptive water uses. While the extent of irrigation and related water uses are reported in statistical databases or estimated by model simulations, information on the source of irrigation water is scarce and very scattered. Here we present a new global inventory on the extent of areas irrigated with groundwater, surface water or non-conventional sources, and we determine the related consumptive water uses. The inventory provides data for 15038 national and sub-national administrative units. Irrigated area was provided by census-based statistics from international and national organizations. A global model was then applied to simulate consumptive water uses for irrigation by water source. Globally, area equipped for irrigation is currently about 301 million ha of which $38 \%$ are equipped for irrigation with groundwater. Total consumptive groundwater use for irrigation is estimated as $545 \mathrm{~km}^{3} \mathrm{yr}^{-1}$, or $43 \%$ of the total consumptive irrigation water use of $1277 \mathrm{~km}^{3} \mathrm{yr}^{-1}$. The countries with the largest extent of areas equipped for irrigation with groundwater, in absolute terms, are India (39 million ha), China (19 million ha) and the USA (17 million ha). Groundwater use in irrigation is increasing both in absolute terms and in percentage of total irrigation, leading in places to concentrations of users exploiting groundwater storage at rates above groundwater recharge. Despite the uncertainties associated with statistical data available to track patterns and growth of groundwater use for irrigation, the inventory presented here is a major step towards a more informed assessment of agricultural water use and its consequences for the global water cycle.
\end{abstract}

Correspondence to: S. Siebert

(s.siebert@uni-bonn.de)

\section{Introduction}

For many important agricultural production areas, groundwater will remain the ultimate source of freshwater when surface water sources have been depleted. The aquifers that host groundwater are the primary buffers against drought for both human requirements, and crop production. In many concentrations of intensive agriculture, groundwater offers reliability and flexibility in access to water that irrigation canals can hardly match. Additionally, groundwater is generally less prone to pollution than surface water. While the rising importance of groundwater withdrawals in global freshwater supply is well established, there is still a large uncertainty on the volumes and spatial distribution of both groundwater recharge and withdrawals. Using a global hydrological model, mean annual direct groundwater recharge was estimated at $12600 \mathrm{~km}^{3} \mathrm{yr}^{-1}$ which is about one third of the total renewable freshwater resources (Döll, 2009). However, this global estimate explicitly excludes indirect recharge resulting from runoff events and transmission losses. These indirect recharge processes are dominant in semi-arid and arid countries where interior or coastal alluvial plains receive high volumes of runoff from surrounding mountain fronts (Scanlon et al., 2007). The Tihama and Batinah coastal plains in Yemen and Oman are prime examples. Total groundwater withdrawals are estimated to be in the range $600-1100 \mathrm{~km}^{3} \mathrm{yr}^{-1}$ or between one fifth and one third of the total global freshwater withdrawals (Döll, 2009; Shah et al., 2007; Zektser and Everett, 2004). There are large regional differences in the patterns of aquifer recharge and groundwater withdrawals. Recharge of aquifers is mainly influenced by three environmental factors: hydrometeorological influences that include the intensity, duration and volume of the precipitation and the ambient atmospheric conditions; the

Published by Copernicus Publications on behalf of the European Geosciences Union. 
hydrogeological influences that include the geomorphology, geology and pedology of the land surface where the precipitation occurs or over which runoff subsequently flows; and the type of vegetation cover and land use. In humid regions, groundwater recharge is likely to exceed groundwater withdrawals such that groundwater discharge contributes significantly to river flows (the base flow component). In semi-arid and arid regions, high water withdrawals are required by the agricultural sector as it takes advantage of long growing seasons, high insolation and low pest and disease risk. Generally, the rates of groundwater recharge in these semi-arid and arid regions are low such that, in the absence of alternative sources of water, groundwater withdrawals can exceed aquifer recharge and can result in depletion. Aquifer depletion has been reported for many semi-arid and arid regions world-wide and can be attributed to agricultural withdrawals (Ahmed and Umar, 2009; Central Groundwater Board, 2006; Foster and Loucks, 2006; Guzman-Soria et al., 2009; Konikow and Kendy, 2005; Rodell et al., 2009; Scanlon et al., 2007; Shah et al., 2007; Wang et al., 2009).

Globally, irrigation accounts for more than $70 \%$ of total water withdrawals and for more than $90 \%$ of total consumptive water use (Döll, 2009; FAO, 2010; Shiklomanov et al., 2000). Therefore, to better understand the impact of human water use on the water cycle, it is necessary to identify the source of the water used for irrigation. Up to now, three different approaches have been used to determine irrigated areas that are supplied by groundwater and the related water uses. First, using the statistical data reported in FAO's AQUASTAT data base at the country level, it was estimated that the area irrigated with groundwater was 89 million ha or $37 \%$ of the total area equipped for irrigation (Burke, 2002). To our knowledge this has been the first quantitative estimate of the global extent of areas equipped for irrigation with groundwater. This estimate was based on data for 63 of the 137 countries with irrigation. $56 \%$ of the global area equipped for irrigation was located in countries for which data on the extent of groundwater irrigation was available. Most of the statistics considered in this estimate referred to the 1990s. For the remaining countries area irrigated with groundwater was determined by expert judgement.

Second, Shah et al. (2007) collected information from many different sources and estimated the area irrigated with groundwater in the range 83-576 million ha. Here, uncertainties lie mainly in the use of different definitions for irrigated land. In addition to this, the source of irrigation water is not reported in the official statistics for many countries, while in other countries the extent of groundwater irrigation area is systematically underestimated in the statistics, in particular in regions with a very dynamic development of groundwater irrigation (Giordano, 2006; Shah et al., 2007). Finally, as with estimated irrigated areas serviced by groundwater irrigation, there is also a large uncertainty in the statistics regarding the related water use. It was estimated that groundwater contributes to $20 \%$ of the global irrigation water withdrawals, to $40 \%$ of the total industrial water withdrawals and to $50 \%$ of the total municipal water withdrawal (Zekster and Everett, 2004).

Third, Thenkabail et al. (2009) developed a global irrigation map that is mainly based on remote sensing. Their final classification contains 28 land use classes and represents a combination of crop type and water source. According to this inventory, $54 \%$ of the total area available for irrigation is irrigated with surface water, $5 \%$ with groundwater, and $41 \%$ by conjunctive use of both water sources with less than $15 \%$ surface water contribution in conjunctive use. Major limitations for this data set were identified: the coarse spatial resolution of the satellite imagery used to develop the data set; the class labelling process which was based on subjective criteria making a reproduction of the classification difficult or impossible; and the fact that sub pixel-fractions were constant all over the world for all pixels belonging to the same class resulting in a significant, albeit not estimated, level of uncertainty (Ozdogan and Gutman, 2008; Pervez et al., 2008; Siebert et al., 2006; Thenkabail et al., 2009). In addition, the methods used to distinguish groundwater and surface water irrigation and to quantify the contribution of surface water in conjunctive use are not described.

Finally, global hydrological models with a spatial resolution of 0.5 degree by 0.5 degree were used to estimate the fraction of irrigation water withdrawals that cannot be met by local renewable water sources (Rost et al., 2008; Wisser et al., 2009; Döll et al., 2009). Depending on the modelling approach, results vary between $20 \%$ and $50 \%$ of irrigation requirements. However, the fraction does not permit estimation of groundwater use in irrigation since it includes both non-renewable groundwater resources and long-distance surface water transfers e.g. via irrigation canal networks, and because the local renewable water resources include both surface water and groundwater resources.

Thus, it appears very difficult to determine groundwater use for irrigation by either remote sensing or modelling. Acknowledging of the severe limitations of statistical data on groundwater use, we think that compilation of statistical data is still the preferred approach. Hence, we present a new global inventory that indicates the source of irrigation water of areas equipped for irrigation (AEI) and of areas actually irrigated (AAI) for 15038 national and subnational administrative units. The inventory is mainly based on statistics published in national census reports available on-line or made available from the FAO-AQUASTAT library. In addition, by linking these statistics to the Global Crop Water Model GCWM (Siebert and Döll, 2010), consumptive irrigation water use from groundwater and surface water is estimated. The inventory and the underlying data are available at http://www.fao.org/nr/water/ aquastat/irrigationmap/index.stm as component of FAO's AQUASTAT information system. In this publication we 
document first the data, definitions and methods used in the development of the inventory (Sect. 2). Then we show results at the global, regional and country scale (Sect. 3), we discuss the major uncertainties and limitations and compare our results to independent estimates (Sect. 4). For a complete country-wise documentation of data sources and assumptions made when developing the data set readers are referred to Supplement S1. Area equipped for irrigation, area actually irrigated and the consumptive water use from groundwater, surface water and non-conventional water sources are listed for each country in Supplement S2, in addition to tables and figures shown in the manuscript. Supplement S3 provides the countries in each continent, region and sub-region, while the acronyms used in this article are listed and explained in Supplement S4.

\section{Definitions, data and methods}

\subsection{Terms and definitions}

Groundwater is usually defined as water contained in an aquifer matrix located beneath the surface in the saturated zone, as opposed to free surface water bodies like streams, reservoirs, or lakes. But clearly the dynamic exchange between groundwater and surface water through the hydrological cycle is complex and makes categorical definitions problematic: groundwater may become surface water through springs and drainage into rivers, lakes and wetlands. Conversely, surface water bodies may seep into the ground and recharge the aquifers, e.g. when flood water percolates through the unsaturated zone to the saturated zone. However, to be consistent with definitions in many water use statistics, we distinguish three possible types of water: groundwater, surface water and non-conventional water sources. Water withdrawn from aquifers using wells, and water taken from springs is considered to be groundwater. Water extracted directly from rivers, lakes, ponds, reservoirs or wetlands is defined as surface water while treated wastewater and desalinated water are considered to be non-conventional sources of water. Surface water that infiltrates aquifers due to groundwater pumping close to the surface water body and is extracted from the groundwater (bank filtrates) are in general categorised as groundwater. The term conjunctive use of groundwater and surface water refers to the intentional use of both water sources.

With regard to irrigation practice, definitions are used in this article according to the FAO AQUASTAT glossary (http://www.fao.org/nr/water/aquastat/data/ glossary/search.html?lang=en). First, the area equipped for irrigation (AEI) is the area of the land that is equipped with infrastructure to provide water to crops. It includes areas equipped for full/partial control irrigation, equipped lowland areas, and areas equipped for spate irrigation. Second, the area actually irrigated (AAI) and the irrigated area harvested (AHI) denote the portion of the area equipped for irrigation that is actually irrigated in a given year. The AAI refers to physical areas and irrigated land that is cultivated more than once a year is counted only once, while in the case of the AHI, land area that is harvested and irrigated more than once in the same year is counted double or threefold, depending on the number of crop harvests on the same area. Consequently AAI is always smaller or equal to AEI and AHI.

\subsection{Data and methods}

\subsubsection{Subdivision of irrigated areas into areas irrigated with groundwater, surface water or non-conventional water sources}

Statistics on area equipped for irrigation with groundwater (AEI_GW), with surface water (AEI_SW) or with water derived from non-conventional sources (AEI_NC) and on area actually irrigated with groundwater (AAI_GW), with surface water (AAI_SW) or with water from non-conventional sources (AAI_NC) were collected from national census reports or online data bases and complemented with country information available from the FAO-AQUASTAT library, data collected by other international organizations or statistical services (e.g. Eurostat) or data taken from the literature. The inventory contains statistics for 15038 national or sub-national administrative units (Fig. 1).

For many countries the statistics on AEI are consistent with data used to develop version 4 of the Global Map of Irrigation Areas (GMIA; Siebert et al., 2005 updated by Siebert et al., 2006) because the same sources of information were used. However, for several countries more recent statistics became available and replaced the GMIA statistics. For almost all countries it was required to fill gaps in the statistics caused by missing data. Furthermore, AEI is reported in most cases as part of land use statistics while AAI is usually collected as part of water use surveys. Therefore in many countries different ministries are responsible to process the data and to provide the statistics resulting in different reference years and different resolution of the statistics. We used the following rules for the selection of statistics used for this inventory and to fill data gaps:

1. Statistics provided at high resolution, for the most recent reference year and using similar definitions, were preferred unless proved wrong (see Supplement S1).

2. If statistics on AEI were available at higher resolution as compared to AAI statistics, then AAI was downscaled by using the ratio between AAI and AEI reported at lower resolution (e.g. if the ratio between AAI and AEI was 0.8 for a first level administrative unit and for the second level administrative units only AEI was known, then AAI was computed as $80 \%$ of AEI for all the second-level administrative units). 
Table 1. Type of census statistics used to define irrigated area by source of irrigation water, number and percentage of administrative units or percentage of global area equipped for irrigation (AEI) for which the different variables were used.

\begin{tabular}{lrrr}
\hline $\begin{array}{l}\text { Variables used to define irrigated } \\
\text { area by source of irrigation water }\end{array}$ & $\begin{array}{r}\text { Administrative } \\
\text { units (number) }\end{array}$ & $\begin{array}{r}\text { Administrative } \\
\text { units (\%) }\end{array}$ & $\begin{array}{c}\text { AEI separated } \\
\text { into groundwater } \\
\text { and surface water } \\
\text { supply (\%) }\end{array}$ \\
\hline $\begin{array}{l}\text { Area equipped for irrigation with } \\
\text { groundwater, surface water or water } \\
\text { from non-conventional sources }\end{array}$ & 554 & 3.7 & 38.6 \\
$\begin{array}{l}\text { Area actually irrigated with } \\
\text { groundwater, surface water or water } \\
\text { from non-conventional sources }\end{array}$ & 1185 & 7.9 & 36.7 \\
$\begin{array}{l}\text { Irrigation water use from } \\
\text { groundwater, surface water or } \\
\text { non-conventional water sources }\end{array}$ & 7274 & 48.4 & 17.3 \\
Other data or own estimate & 5984 & 39.8 & 7.3 \\
\hline No irrigation & 41 & 0.3 & 0.0 \\
\hline Total & 15038 & 100.0 & 100.0 \\
\hline
\end{tabular}

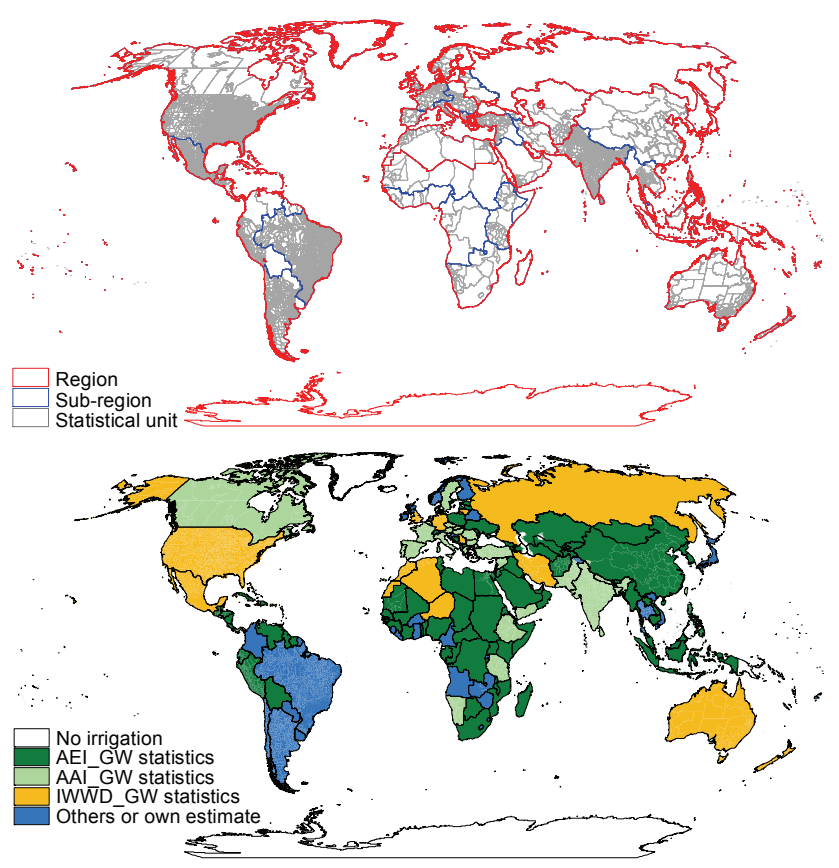

Fig. 1. Regions and sub-regions used in this paper as well as administrative units distinguished in the groundwater irrigation inventory (top), and type of input data used to develop the inventory (bottom). AEI_GW = area equipped for irrigation with groundwater, AAI_GW = area actually irrigated with groundwater, IWWD_GW = groundwater withdrawals for irrigation (see the electronic Supplement for a high resolution version of this figure).
3. If statistics on the source of irrigation water were available for AEI only or for AAI only, then the fraction of area irrigated with water from the different sources was assumed to be the same, e.g. if $15 \%$ of the AEI was reported to be irrigated with groundwater and AAI_GW was unknown, then AAI_GW was set to $15 \%$ of total AAI as well.

4. If the extent of AEI and AAI irrigated with water from the different sources was unknown but irrigation water use from different sources was reported, then the water use statistics were used to downscale the irrigated area statistics (e.g. if $20 \%$ of irrigation water use was from groundwater, then it was assumed that also $20 \%$ of AEI and of AAI were irrigated with groundwater).

5. If for specific countries the source of irrigation water was unknown for AEI and AAI and water use statistics were not available as well, the percentage of AEI and AAI irrigated with groundwater, surface water or non-conventional sources was estimated based on other information, e.g. qualitative estimates in the literature, based on borehole inventories or based on the availability of water resources.

6. Areas with conjunctive use of groundwater and surface water were assigned with $50 \%$ to AEI_GW and $50 \%$ to AEI_SW if not otherwise noted. 
For only about $12 \%$ of the 15038 administrative units, statistics on AEI or AAI by source of water have been available (Fig. 1 and Table 1). However, about $75 \%$ of the global AEI is located in these 1739 administrative units. For 7274 administrative units containing $17 \%$ of the total AEI, water use statistics were used to compute AEI_GW, AEI_SW and AEINC. For 6025 administrative units containing 7\% of the global AEI, other data or own estimates were applied. The data for the different spatial units represent different periods of time, such that it is impossible to state exactly for which time period this global inventory is representative. In many units, however, the situation around the year 2000 is represented. For a detailed country-wise description of input data, references and methods used to develop this inventory, readers are referred to Supplement S1.

\subsubsection{Calculation of consumptive water use in irrigation and breakdown by water sources}

Average consumptive use of irrigation water was computed for each administrative unit using the Global Crop Water Model GCWM (Siebert and Döll, 2010). It was then subdivided into irrigation consumptive water use from groundwater (ICWU_GW), irrigation consumptive water use from surface water (ICWU_SW) and irrigation consumptive water use from non-conventional water sources (ICWU_NC) using the ratios of AAI_GW, AAI_SW and AAI_NC to total AAI. GCWM was applied using climate data for the period 1998-2002, and the FAO Penman-Monteith method (Allen et al., 1998) was used to compute reference evapotranspiration. In GCWM irrigation consumptive water use is computed as the difference between potential crop evapotranspiration (calculated as reference evapotranspiration multiplied by a crop and growing stage specific "crop factor") and water limited actual evapotranspiration of the same crop under rainfed conditions. The model considers 26 different crop classes and evapotranspiration is simulated based on a soil water balance performed in daily time steps. Cropping patterns and cropping seasons are provided by MIRCA2000 (Portmann et al., 2010), a global data set of monthly irrigated and rainfed crop areas of these 26 crop classes at 5 arc-min resolution and mainly based on FAO cropping calendars and cropping factors. The growing areas of irrigated crops in MIRCA2000 are consistent with version 4 of the global map of irrigation areas but not with the inventory of irrigation areas presented here because the irrigated area database was updated with new information in many administrative units (see Sect. 2.2.1 and Supplement S1). Therefore, a scaling procedure was applied to adapt the water uses computed with GCWM based on MIRCA2000 to irrigated area statistics used in this inventory.

Irrigation water use is more closely related to AAI than to AEI. A scaling coefficient based on AAI per administrative unit in this inventory as compared to MIRCA2000, however, could not be computed because AAI is not reported by
MIRCA2000. Therefore, a scaling coefficient $c s_{1}$ was computed for each administrative unit as

$c s_{1}=\frac{\mathrm{AEI}}{\mathrm{AEI}_{\mathrm{MIRCA}}}$

where AEI was the area equipped for irrigation recorded in the new inventory (ha) and $\mathrm{AEI}_{\mathrm{MIRCA}}$ was the area equipped for irrigation used for the same administrative unit when developing the MIRCA2000 data set (ha). Then, a second scaling coefficient $c s_{2}$ was computed as

$c s_{2}=\left\{\begin{array}{cl}\frac{\mathrm{AAI}}{c s_{1} \times \mathrm{AHI}_{\mathrm{IIRCA}}} & \text { if } \text { AAI }>c s_{1} \times \mathrm{AHI}_{\mathrm{MIRCA}} \\ \frac{\mathrm{AAI}}{c s_{1} \times \mathrm{MMGA} \mathrm{AMIRCA}_{\mathrm{M}}} & \text { if } \text { AAI }<c s_{1} \times \mathrm{MMGA}_{\mathrm{MIRCA}} \\ 1 & \text { else }\end{array}\right.$

where AAI was the area actually irrigated recorded in the new inventory (ha), $\mathrm{AHI}_{\mathrm{MIRCA}}$ was the harvested area of irrigated crops in MIRCA2000 (ha) and MMGA MIRCA was $_{2}$ the maximum of the sum of monthly growing areas of all irrigated crops in MIRCA2000 (ha). MMGA MIRCA was computed by adding up in each 5 arc-minute grid cell the growing area of all irrigated crops for each month and by afterwards selecting the maximum of the 12 total monthly growing areas. $\mathrm{AHI}_{\mathrm{MIRCA}}$ is larger than $\mathrm{MMGA}_{\mathrm{MIRCA}}$ when irrigated crops are cultivated in different seasons without an overlap of the growing season, e.g. when multi-cropping occurs. Therefore AAI has to be larger or equal to MMGA $_{\text {MIRCA }}$ and lower or equal to $\mathrm{AHI}_{\mathrm{MIRCA}}$ which is reflected by Eq. (2). The adjusted irrigation water use was then computed for each administrative unit as

$\mathrm{ICWU}=c s_{1} \times c s_{2} \times \mathrm{ICWU}_{\mathrm{GCWM}}$

where ICWU was the consumptive use of irrigation water in the new inventory $\left(\mathrm{m}^{3} \mathrm{yr}^{-1}\right)$ and ICWU $\mathrm{GCWM}$ was the consumptive use of irrigation water as computed by GCWM using the MIRCA2000 crop data $\left(\mathrm{m}^{3} \mathrm{yr}^{-1}\right)$.

In 443 administrative units with an AEI of 377978 ha $(0.12 \%$ of total AEI), AAI was larger than 0 in the new inventory but $\mathrm{AEI}_{\mathrm{MIRCA}}$ and $\mathrm{ICWU}_{\mathrm{GCWM}}$ was zero. This happened mainly in regions where the resolution of the irrigation statistics was much higher in the new inventory as compared to the resolution of the statistics in version 4 of the global irrigation map as used when developing MIRCA2000 (e.g. in Mexico and Chile). ICWU for these administrative units was computed by interpolating ICWU $_{\mathrm{GCWM}}$ per $\mathrm{MMGA}_{\mathrm{MIRCA}}$ from grid cells belonging to neighbouring administrative units and by multiplying this interpolated ratio with the reported AAI.

\section{Results}

\subsection{Irrigated area and consumptive irrigation water use}

Total AEI recorded in this inventory is 301 million ha while total AAI is 253 million ha, i.e. about $84 \%$ of the equipped 
Table 2. Total area equipped for irrigation (AEI), area equipped for irrigation irrigated with groundwater (AEI_GW), total area actually irrigated (AAI_TOT), area actually irrigated with groundwater (AAI_GW), total consumptive irrigation water use (ICWU) and consumptive groundwater use for irrigation (ICWU_GW) per continent, region and sub-region.

\begin{tabular}{|c|c|c|c|c|c|c|c|}
\hline Continent, region or sub-region & $\begin{array}{l}\text { AEI } \\
\text { (ha) }\end{array}$ & $\begin{array}{c}\text { AEI_GW } \\
\text { (ha) }\end{array}$ & $\begin{array}{c}\text { AEI_GW } \\
(\%)\end{array}$ & $\begin{array}{l}\text { AAI_TOT } \\
\text { (ha) }\end{array}$ & $\begin{array}{l}\text { AAI_GW } \\
\text { (ha) }\end{array}$ & $\begin{array}{c}\text { ICWU } \\
\left(\mathrm{Mm}^{3} \mathrm{yr}^{-1}\right)\end{array}$ & $\begin{array}{l}\text { ICWU_GW } \\
\left(\mathrm{Mm}^{3} \mathrm{yr}^{-1}\right)\end{array}$ \\
\hline Africa & 13576142 & 2505954 & 18.5 & 11527882 & 2157978 & 98251 & 17863 \\
\hline Sub-Saharan Africa & 7198316 & 413758 & 5.7 & 5510258 & 340134 & 32886 & 2178 \\
\hline Central Africa & 132439 & 17000 & 12.8 & 81893 & 8000 & 464 & 50 \\
\hline Eastern Africa & 622059 & 21285 & 3.4 & 612617 & 21190 & 2922 & 117 \\
\hline Southern Africa & 2063428 & 157991 & 7.7 & 1925095 & 151369 & 11478 & 908 \\
\hline Sudano-Sahelian & 2667130 & 123226 & 4.6 & 1296745 & 69923 & 12958 & 655 \\
\hline America & 48903652 & 21548173 & 44.1 & 39556109 & 17621335 & 224238 & 107358 \\
\hline Central America and Caribbean & 1895292 & 683462 & 36.1 & 1054535 & 324967 & 4179 & 1252 \\
\hline Caribbean - Greater Antilles & 1332107 & 527271 & 39.6 & 547587 & 186845 & 1743 & 519 \\
\hline Northern America & 29037745 & 16657638 & 57.4 & 23281812 & 13547200 & 158619 & 88498 \\
\hline Southern America & 11551811 & 1717288 & 14.9 & 9571215 & 1558158 & 34276 & 6221 \\
\hline Andean & 4180641 & 660447 & 15.8 & 3493609 & 560205 & 13664 & 2619 \\
\hline Brazil & 3149217 & 591439 & 18.8 & 3149217 & 591439 & 9576 & 2154 \\
\hline Guyana & 207348 & 302 & 0.1 & 207038 & 286 & 431 & $<0.5$ \\
\hline Southern America & 4014606 & 465100 & 11.6 & 2721351 & 406227 & 10606 & 1447 \\
\hline Asia & 211796335 & 80582458 & 38.0 & 185139307 & 72531008 & 890679 & 398631 \\
\hline Central Asia & 14673971 & 1149245 & 7.8 & 11787249 & 780969 & 67696 & 4719 \\
\hline Middle East & 23562117 & 10838415 & 46.0 & 17749167 & 9059714 & 130813 & 71261 \\
\hline Arabian Peninsula & 2791906 & 2467433 & 88.4 & 2221846 & 1938015 & 23559 & 20759 \\
\hline Caucasus & 2132320 & 147577 & 6.9 & 1402060 & 107329 & 6696 & 501 \\
\hline Eastern Europe & 4898893 & 493257 & 10.1 & 1708100 & 342734 & 4983 & 861 \\
\hline Eastern Europe & 2523793 & 18237 & 0.7 & 768900 & 4622 & 2606 & 6 \\
\hline Russian Federation & 2375100 & 475020 & 20.0 & 939200 & 338112 & 2377 & 856 \\
\hline Western and Central Europe & 17752891 & 6856671 & 38.6 & 11593398 & 4474201 & 42902 & 17344 \\
\hline Central Europe & 2418969 & 302049 & 12.5 & 909437 & 118233 & 1986 & 264 \\
\hline Mediterranean Europe & 10375898 & 3920338 & 37.8 & 7942875 & 2963597 & 36486 & 15179 \\
\hline Northern Europe & 859696 & 520927 & 60.6 & 313280 & 224467 & 119 & 66 \\
\hline Western Europe & 4098328 & 2113358 & 51.6 & 2427806 & 1167904 & 4310 & 1836 \\
\hline Oceania & 3967179 & 949921 & 23.9 & 3054250 & 693923 & 15880 & 3301 \\
\hline Australia and New Zealand & 3962741 & 949172 & 24.0 & 3049812 & 693174 & 15880 & 3301 \\
\hline Other Pacific Islands & 4438 & 749 & 16.9 & 4438 & 749 & $<0.5$ & $<0.5$ \\
\hline WORLD & 300895091 & 112936434 & 37.5 & 252579046 & 97821180 & 1276932 & 545359 \\
\hline
\end{tabular}


area is actually irrigated. Total ICWU computed using GCWM is $1277 \mathrm{~km}^{3} \mathrm{yr}^{-1}$ corresponding to $506 \mathrm{~mm} \mathrm{yr}^{-1}$ of irrigation water consumed by the crops on average and related to AAI. About $70 \%$ of the AEI is recorded for Asian countries, $16 \%$ is located in America, $8 \%$ in Europe, $5 \%$ in Africa and $1 \%$ in Oceania (Table 2). At the country scale the largest extent of AEI is reported for China (62 million ha), India (62 million ha), the USA (28 million ha), and Pakistan ( 17 million ha). About $56 \%$ of the total AEI is located in these four countries (Supplement S2). The percentage of cultivated land that is equipped for irrigation is largest in Asia (37\%) while it is smallest for the African continent (5\%) (Table 3). At the sub-regional scale AEI as percentage of cultivated land is largest in the sub-regions of Caucasus (68\%), Arabian Peninsula (49\%), Islamic Republic of Iran (45\%), South Asia (42\%) and East Asia (41\%) while it is less than $1 \%$ for the Pacific Islands, Central Africa and the Gulf of Guinea (Table 3). We computed a consumptive water use for irrigation larger than the total internal renewable water resources for the sub-regions Northern Africa and Arabian Peninsula (Table 3), indicating over-exploitation of existing water resources by irrigation (Arabian Peninsula) or a dependency on external water resources (inflow of river Nile water into the sub-region of Northern Africa). More than $25 \%$ of the internal renewable water resources are used for irrigation in the sub-regions of Islamic Republic of Iran, South Asia and Central Asia (Table 3).

The estimated consumptive water use for irrigation (ICWU) comprises both evaporation $(E)$ and transpiration $(T)$, and is calculated over cropped areas as the difference between crop evapotranspiration under no-stress conditions and crop evapotranspiration under rainfed circumstances. In the case of paddy rice, also a certain amount of water needs to be added for crop water management on the field, but the ICWU does not account for this additional water requirement. When calculated as a percentage of reported agricultural water withdrawals AWWD (FAO, 2010) it can be taken as a notional indicator of irrigation "efficiency" because irrigation water withdrawals represent by far the largest part of total agricultural water withdrawals in most countries, much more than direct water use for livestock (stock-watering, washing and cooling). In the following we refer to the ratio of ICWU and AWWD as the consumptive fraction. At the field scale the consumptive fraction depends on the method of water application (surface, sprinkler or localized irrigation), on the soil properties, the size of the basins when surface irrigation is being used, on the climate conditions and other factors. Low consumptive fractions of 0.2 or even lower were reported for flooded paddy rice cultivation while large consumptive fractions of more than 0.8 can be achieved when using localized irrigation. However, the consumptive fraction at the scale of a large irrigation scheme or a river basin can be much higher when drainage water is reused several times in the downstream area. While for example in Egypt the consumptive fraction at scheme level may be rather low, it is higher at basin level due to the reuse of agricultural drainage water in downstream schemes. The consumptive fractions computed here for regions and sub-regions (Table 3) are used to check the consistency of computed ICWU to reported AWWD. The largest consumptive fractions were computed for Australia and New Zealand (0.84), Northern Africa (0.82) and the Arabian Peninsula (0.81) while lowest consumptive fractions were computed for Northern Europe (0.11), Eastern Europe (0.12), the Russian Federation (0.18), Guyana, Greater Antilles and Indian Ocean Islands (0.19), Mainland Southeast Asia (0.22) and Maritime Southeast Asia (0.23). The large values of ICWU as a fraction of AWWD in Northern Africa may be realistic because of the reuse of drainage water in the large irrigation schemes along the Nile river in Egypt (Oosterbaan, 1999) while the low values for Southeast Asia may reflect the importance of paddy cultivation in this region. In contrast, the low consumptive fractions computed for Northern Europe, Eastern Europe and the Russian Federation may be caused by the importance of other agricultural water uses (livestock, fish ponds) in Northern Europe or indicate an overestimation of current agricultural water withdrawals in the statistical data used here. For example, AWWD reported by FAO-AQUASTAT for Sweden was 260 million $\mathrm{m}^{3} \mathrm{yr}^{-1}$ in year 2000 while ICWU computed here was 48 million $\mathrm{m}^{3} \mathrm{yr}^{-1}$ (Supplement S2) resulting in a consumptive fraction of 0.19 . In contrast, national statistics reported an AWWD of 132 million $\mathrm{m}^{3} \mathrm{yr}^{-1}$ for year 2005, of which 94 million $\mathrm{m}^{3} \mathrm{yr}^{-1}$ (71\%) was for irrigation (Statistics Sweden, 2007). However, it should be noted that even the national statistics for irrigation water withdrawals are based on a survey undertaken in year 1985 and reflecting water uses that would occur in a dry year (Brånvall et al., 1999; Statistics Sweden, 2007). Another example is the Russian Federation. The latest available statistics on AWWD in FAO-AQUASTAT refer to year $2001\left(13.2 \mathrm{~km}^{3} \mathrm{yr}^{-1}\right)$. ICWU computed here for the Russian Federation was $2.4 \mathrm{~km}^{3} \mathrm{yr}^{-1}$ (Supplement S2) resulting in a consumptive fraction of 0.18 . National statistics reported an AWWD of $8.5 \mathrm{~km}^{3} \mathrm{yr}^{-1}$ in year 2005 based on an irrigated area of 4.6 million ha (Federal State Statistics Service, 2006). However, according to the results of the agricultural census undertaken in year 2006 AEI was only 2.38 million ha, of which 0.94 million ha were actually irrigated in year 2006 (Federal State Statistics Service, 2008). Therefore AWWD is very likely much lower than estimated in the national water use statistics.

\subsection{Importance of groundwater use for irrigation}

The total area equipped for irrigation with groundwater (AEI_GW) is 113 million ha or $38 \%$ of total AEI, while the total area actually used for groundwater irrigation (AAI_GW) is 98 million ha or $39 \%$ of total AAI (Table 2). Computed consumptive groundwater use for irrigation (ICWU_GW) is 
Table 3. Area equipped for irrigation as percentage of cultivated land (AEI_CULT), consumptive irrigation water use as percentage of total internal renewable water resources (ICWU_REN), consumptive irrigation water use as fraction of agricultural water withdrawals (ICWU_AWWD) and consumptive groundwater use for irrigation as percentage of internally produced groundwater (ICWU_GW_REN) per continent, region and sub-region (cultivated land, internal renewable water resources, agricultural water withdrawals and internally produced groundwater per country was derived from the FAO AQUASTAT main country database, http://www.fao.org/nr/water/aquastat/data/query/ index.html?lang=en, last access: 16 March 2010).

\begin{tabular}{|c|c|c|c|c|}
\hline $\begin{array}{l}\text { Continent, region or } \\
\text { sub-region }\end{array}$ & AEI_CULT & ICWU_REN & ICWU_AWWD & ICWU_GW_REN \\
\hline Africa & 5.5 & 2.5 & 0.53 & 1.3 \\
\hline Northern Africa & 22.9 & 139.5 & 0.82 & 106.1 \\
\hline Sub-Saharan Africa & 3.3 & 0.8 & 0.31 & 0.2 \\
\hline Central Africa & 0.6 & $<0.1$ & 0.42 & $<0.1$ \\
\hline Eastern Africa & 1.5 & 1.0 & 0.24 & 0.1 \\
\hline Gulf of Guinea & 0.9 & 0.2 & 0.25 & 0.2 \\
\hline Indian Ocean Islands & 29.3 & 0.8 & 0.19 & $<0.1$ \\
\hline Southern Africa & 6.1 & 4.2 & 0.76 & 1.1 \\
\hline Sudano-Sahelian & 4.9 & 8.1 & 0.25 & 1.1 \\
\hline America & 12.4 & 1.2 & 0.58 & n.a. \\
\hline $\begin{array}{l}\text { Central America and } \\
\text { Caribbean }\end{array}$ & 12.3 & 0.5 & 0.28 & n.a. \\
\hline Caribbean - Greater Antilles & 19.3 & 2.0 & 0.19 & 2.1 \\
\hline Caribbean - Lesser Antilles & 9.2 & 0.6 & 0.56 & n.a. \\
\hline Central America & 6.5 & 0.4 & 0.41 & 0.4 \\
\hline Northern America & 14.1 & 3.1 & 0.71 & 5.5 \\
\hline Mexico & 23.9 & 6.6 & 0.45 & 8.2 \\
\hline Northern America & 12.9 & 2.8 & 0.79 & 5.3 \\
\hline Southern America & 9.2 & 0.3 & 0.31 & 0.2 \\
\hline Andean & 23.6 & 0.3 & 0.34 & 0.2 \\
\hline Brazil & 4.7 & 0.2 & 0.26 & 0.1 \\
\hline Guyana & 39.0 & 0.1 & 0.19 & $<0.1$ \\
\hline Southern America & 9.8 & 0.8 & 0.32 & 0.4 \\
\hline Asia & 36.9 & 7.2 & 0.45 & 14.4 \\
\hline Central Asia & 36.5 & 25.7 & 0.45 & 8.4 \\
\hline Middle East & 36.6 & 27.0 & 0.58 & 43.3 \\
\hline Arabian Peninsula & 49.1 & 385.6 & 0.81 & 401.1 \\
\hline Caucasus & 68.4 & 9.2 & 0.55 & 1.8 \\
\hline Islamic Republic of Iran & 44.7 & 36.6 & 0.55 & 61.2 \\
\hline Near East & 27.9 & 19.4 & 0.54 & 24.2 \\
\hline Southern and Eastern Asia & 37.0 & 5.9 & 0.43 & 12.7 \\
\hline East Asia & 41.5 & 4.9 & 0.33 & 6.5 \\
\hline Mainland Southeast Asia & 27.7 & 2.1 & 0.22 & 0.8 \\
\hline Maritime Southeast Asia & 14.8 & 0.5 & 0.23 & 0.1 \\
\hline South Asia & 41.6 & 26.6 & 0.57 & 49.4 \\
\hline Europe & 7.7 & 0.7 & 0.44 & 1.4 \\
\hline Eastern Europe & 2.9 & 0.1 & 0.14 & 0.1 \\
\hline Eastern Europe & 5.6 & 1.9 & 0.12 & $<0.1$ \\
\hline Russian Federation & 1.9 & 0.1 & 0.18 & 0.1 \\
\hline Western and Central Europe & 14.1 & 2.0 & 0.58 & 3.5 \\
\hline Central Europe & 5.9 & 0.7 & 0.57 & 0.4 \\
\hline Mediterranean Europe & 30.6 & 8.6 & 0.59 & 16.2 \\
\hline Northern Europe & 10.6 & $<0.1$ & 0.11 & $<0.1$ \\
\hline Western Europe & 9.6 & 0.7 & 0.51 & 1.0 \\
\hline Oceania & 8.6 & 1.8 & 0.84 & n.a. \\
\hline Australia and New Zealand & 8.7 & 1.9 & 0.84 & n.a. \\
\hline Other Pacific Islands & 0.6 & $<0.1$ & 0.01 & n.a. \\
\hline WORLD & 19.4 & 3.0 & 0.48 & n.a. \\
\hline
\end{tabular}




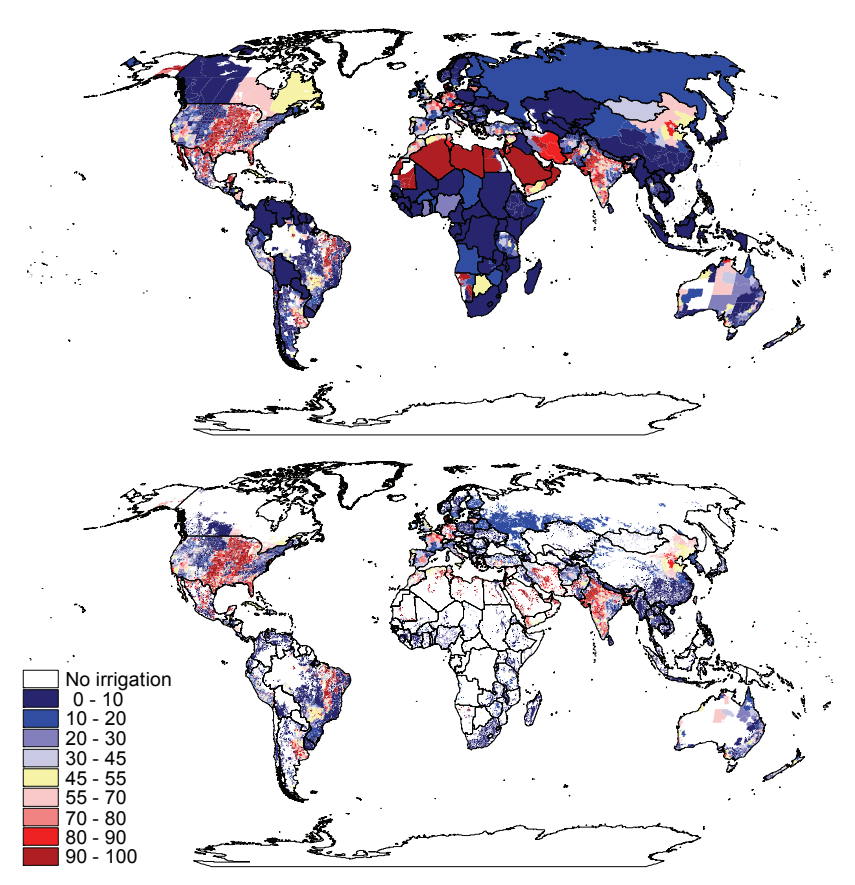

Fig. 2. Percentage of area equipped for irrigation that is irrigated with groundwater per statistical unit (top) and per irrigated grid cell in version 4 of the global map of irrigation areas (Siebert et al., 2006; bottom; see the electronic Supplement for a high resolution version of this figure).

$545 \mathrm{~km}^{3} \mathrm{yr}^{-1}$ (Table 2). The relative importance of groundwater use in irrigation varies strongly among continents, regions, sub-regions (Table 2), countries (Supplement S2) and different agricultural regions within the countries (Supplement S2, Fig. 2). More than half of the AEI is equipped for irrigation with groundwater in the sub-regions Arabian Peninsula (88\%), Islamic Republic of Iran (62\%), Northern Europe (61\%), Northern America (57\%), South Asia (57\%) and Western Europe (52\%) (Table 2). In contrast, it is less than $10 \%$ in 10 out of the 33 sub-regions (Table 2). More than one million ha of AEI_GW are recorded for India (39.4 million ha), China (18.8 million ha), the USA (16.6 million ha), Pakistan (5.2 million ha), Islamic Republic of Iran (5.2 million ha), Bangladesh (3.5 million ha), Mexico (2.5 million ha), Saudi Arabia (1.7 million ha), Turkey (1.7 million ha), Spain (1.4 million ha), Italy ( 1.3 million ha) and France (1.2 millionha). The largest ICWU_GW values were computed for India $\left(204 \mathrm{~km}^{3} \mathrm{yr}^{-1}\right)$, USA $\left(88 \mathrm{~km}^{3} \mathrm{yr}^{-1}\right)$, China $\left(57 \mathrm{~km}^{3} \mathrm{yr}^{-1}\right)$, Pakistan $\left(39 \mathrm{~km}^{3} \mathrm{yr}^{-1}\right)$ and the Islamic Republic of Iran $\left(30 \mathrm{~km}^{3} \mathrm{yr}^{-1}\right)$. In 29 countries ICWU_GW was larger than $1 \mathrm{~km}^{3} \mathrm{yr}^{-1}$ (Supplement S2). ICWU_GW as percentage of internally produced groundwater is largest for the sub-regions Arabian Peninsula (401\%), Northern Africa (106\%), Islamic Republic of Iran (61\%), South Asia (49\%), the Near East (24\%) and Mediterranean Europe (16\%) indicating a large

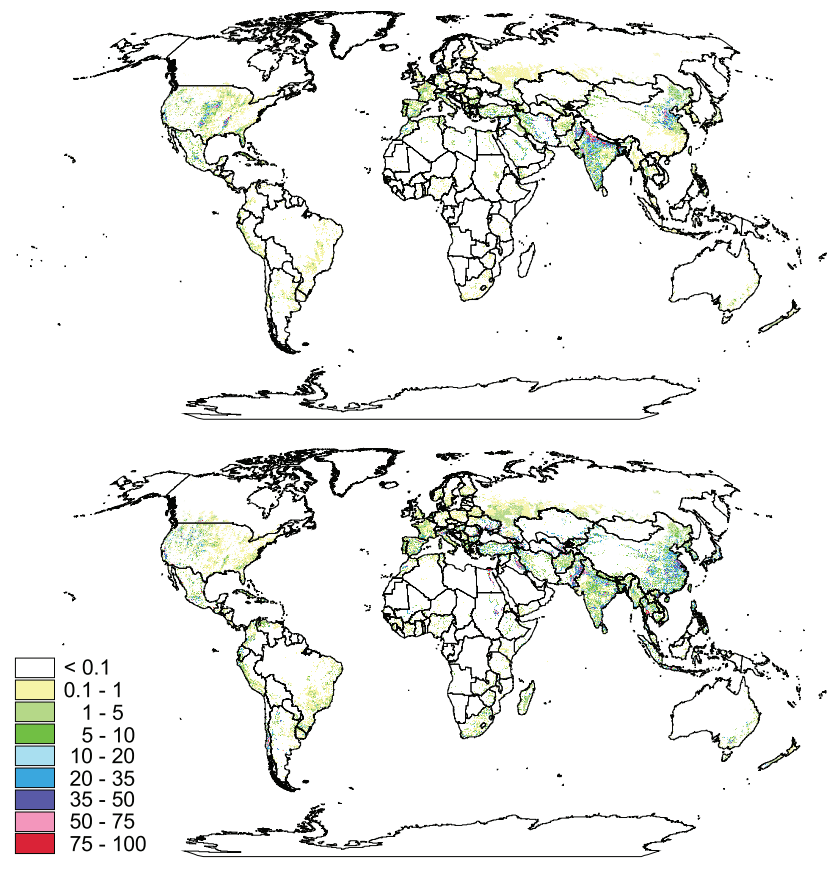

Fig. 3. Percentage of 5 arc min grid cell area equipped for irrigation with groundwater (top) and with surface water (bottom; see the electronic Supplement for a high resolution version of this figure).

pressure of irrigation water use on groundwater resources and at least in case of the Arabian Peninsula and Northern Africa, groundwater over-abstraction and the use of fossil groundwater (Table 3).

At the sub-national scale, areas predominantly irrigated with groundwater (red colours in Fig. 2) are found in a stripe stretching through the whole central part of Northern America, in a stripe of about $500 \mathrm{~km}$ width and $2500 \mathrm{~km}$ length in Brazil, in the north-eastern part of Argentina, in the northern and western part of India, the north-eastern part of China and in large parts of Northern Africa, Western Europe, the whole Arabian Peninsula, the eastern and central part of the Islamic Republic of Iran and the provinces of Punjab and Baluchistan in Pakistan. In contrast, the irrigation sector in Eastern Europe, in the states of the former Soviet Union, in Southeast Asia, the southern part of China, in Sub-Saharan Africa, in the north-western part of the USA, Oceania and in most regions of Southern America mainly uses surface water (Fig. 2). Figure 3, which shows the percentage of each 5 arc min grid cell area equipped for irrigation with groundwater and surface water, takes into account the density of irrigation areas. This map was generated by combining the subnational groundwater inventory to the percentage of grid cell area equipped for irrigation in version 4 of the global map of irrigation areas. The highest density of AEI_GW was mapped for northern India and Pakistan in the 
Ganges and upper Indus watersheds, in Bangladesh, western India, the North China Plain, the High Plains aquifer and the alluvial aquifer along the Mississippi river in the USA and in the major irrigation areas of the Islamic Republic of Iran and Saudi Arabia (Fig. 3 top). In contrast, AEI_SW was concentrated along the river Nile, in the lower Indus basin, the Euphrates Tigris basin in Turkey, Syrian Arab Republic and Iraq, in South China, Thailand, the island of Java (Indonesia), the river Po plain in northern Italy and in the arid regions along the South American west coast in Peru and Chile (Fig. 3 bottom).

\section{Discussion}

\subsection{Limitations of the data used to develop the inventory}

Data on the source of water used for irrigation and on the related areas equipped for irrigation are very scarce for most of the countries. As shown in Sect. 2.2, AEI_GW was available for 554 administrative units containing $39 \%$ of the total AEI. In another $37 \%$ of the total AEI, statistics on the source of water related to AAI was used, $17 \%$ of the AEI was assigned based on water use statistics and 7.3\% based on other data or own estimates (Table 1, Fig. 1). Furthermore, there are large differences in the resolution of the sub-national statistics. Statistics for second level or even third level administrative units were collected for many countries in South Asia, America, Europe and Oceania while for most of the countries in Africa and for the countries of the former Soviet Union only statistics at the national scale were available. Therefore, heterogeneity within these countries is not represented, such that maps with grid cell resolution (like Fig. 3) may be misleading.

Another aspect of uncertainty of the information presented here is the reference year of the statistics used to distinguish AEI_GW, AEI_SW and AEI_NC because the importance of groundwater use for irrigation is changing in time. For the two countries India and USA this is illustrated in Fig. 4. While in year 1920 only about $10 \%$ of the irrigated area in the USA was irrigated with groundwater, this share increased to $35 \%$ in year $1950,55 \%$ in year 1982 and $61 \%$ in year 2003. A similar trend was observed for India, with $29 \%$ of the irrigated area irrigated with groundwater in $1951,38 \%$ in 1971, 51\% in 1991 and 62\% in 2003 (Fig. 4). Consequently, in the USA, area irrigated with groundwater in 2003 is 20 times larger than the area recorded for year 1920. In India, area irrigated with groundwater is nowadays about 5 times larger than the groundwater irrigated area in year 1951. In contrast, total area irrigated with surface water is not increasing anymore in the USA since 1940 and in India since 1981 (Fig. 4). There is no doubt that during the last two decades the percentage of AEI irrigated with groundwater has been increasing in many other countries and

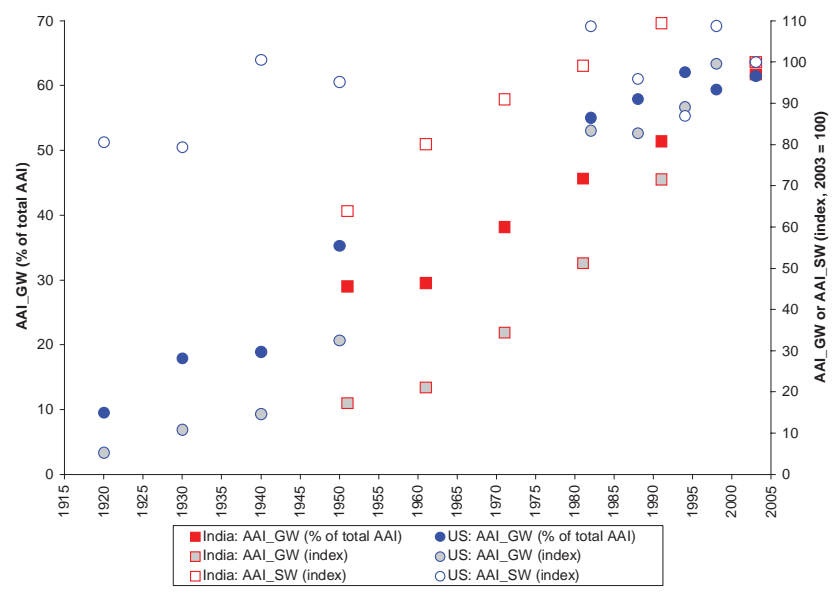

Fig. 4. Historical development of area actually irrigated with groundwater (AAI_GW) as percentage of total actually irrigated area, AAI_GW as index $(2003=100)$, area actually irrigated with surface water (AAI_SW) as index $(2003=100)$ for India and the USA (sources: agricultural census data reported in INDIAAGRISTAT (2010) and Narayanamoorthy (2006) for India and US Department of Commerce (1922, 1932, 1942, 1952, 1984), US Department of Agriculture (1996), Glickman et al. (1999) and Veneman et al. (2004) for the USA).

very likely at the global scale as well (Shah, 2009; Shah et al., 2007), although time series of the related statistics have been available only for very few countries. We therefore consider that AEI_GW is probably underestimated for several countries in the inventory presented here when recent statistics have not been available. For example, AEI_GW was computed for Afghanistan based on statistics related to year 1967 and for Angola based on statistics for year 1975. In 52 administrative units the base year of the statistics has been a year before 1994, and for the other units a year between 1994 and 2007 (Supplement S2). Another reason for expecting an underestimation of groundwater-based irrigation is that areas under groundwater pumping are much less reported in statistics than surface water irrigation areas. This is particularly the case in areas where farmers practice conjunctive use of surface water and groundwater.

\subsection{Limitations of the methodology applied to develop the inventory}

Because of missing data it was required to convert data between AEI_GW and AAI_GW and vice versa. For most of the countries either AEI_GW was reported in the statistics or AAI_GW, but rarely both variables. Furthermore statistics on total AEI and total AAI often have a different resolution (e.g. AEI available for third level administrative units but AAI only at the national scale). The general procedure to deal with those data gaps is described in Sect. 2.2.1 while a detailed description is available for each country in Supplement S1. In most cases of missing data it was 
assumed that the ratio of AEI_GW to total AEI and the ratio of AAI_GW to total AAI were the same. This assumption is not valid in some cases, e.g. when groundwater is mainly used in the private sector and surface water mainly in the public sector and the fractions of AEI that are actually being used differ significantly between the private and public sector. Similar to this, it was assumed that the ratio between ICWU_GW and total ICWU was equal to the ratio between AAI_GW and total AAI, i.e. in each administrative unit, average ICWU per unit AAI was equal for irrigation with groundwater and irrigation with surface water. This assumption represents a simplification of reality and may not hold when groundwater and surface water use is specific to different crops or different seasons, e.g. groundwater use mainly for irrigation of vegetables and surface water use for irrigation of cereals, or for different irrigation technologies, e.g. groundwater may be more often used for pressurized irrigation which also can be more efficient. Additionally, farmers usually manage themselves pumps required to extract groundwater, resulting in a more efficient use of the water resource to reduce costs for energy. In contrast, surface water supply in large irrigation schemes is often centrally planned and occurs with a predefined schedule so that the farmers irrigate when they have access to the water rather than when they need to irrigate because of a soil water deficit.

Another limitation refers to the share of area irrigated with groundwater and with surface water in case of conjunctive use of both resources which is common in many large irrigation schemes across the world, like in Pakistan for example. If no other data was available we applied the rule that in case of conjunctive use half of the area was equipped for irrigation with groundwater and half of the area for irrigation with surface water. In a strict sense this assumption is wrong because in case of conjunctive use the total area is irrigated by both, groundwater and surface water. One positive implication of that rule is that it avoids double counting and we ensure that way that the sum of AEI_GW, AEI_SW and AEI_NC equals total AEI. Furthermore, statistics specific to conjunctive use are available for only a few countries. Splitting of conjunctive use areas into AEI_GW and AEI_SW makes it also possible to compute the related water uses directly from the irrigated areas. The major uncertainty in our approach refers to the assumption of a 50\% share assumed for AEI_GW and AEI_SW. Even in the field it is difficult to identify the accurate ratio of the water sources, e.g. because of the conversions from surface water to groundwater and vice versa.

Shallow aquifers are recharged by percolation losses from irrigation canals or from the irrigated soil. Assuming a plot or scheme irrigation efficiency of $25 \%$, one hectare of AEI_SW could provide enough seepage to irrigate three hectares of AEI_GW. Although in different categories, it is basically the same water that is being applied in this case and there is no easy solution for avoiding double counting of this water.
Even more complex is the situation when groundwater and surface water is applied in different seasons because of the combination of natural and artificial recharge in the shallow aquifer. In contrast, water pumped out of deep aquifers may in some regions form a fraction of the river base flow and thus be converted to surface water when the efficiency of groundwater irrigation is low. While it may be possible to account for all these storages, flows and conversions in models of the water cycle at the local scale, it is impossible to model and assess the water cycle in that detail at the global scale. This highlights the importance of the use of consistent definitions and transparent assumptions in global scale assessments of water resources and water use in order to avoid the generation of additional uncertainties.

In order to estimate AEI_GW and AEI_SW as a fraction of the total 5 arc min grid cell area, we combined the percentage of AEI_GW and AEI_SW recorded in this inventory to version 4 of the global map of irrigation areas (Fig. 3). We need to point out that the statistics on AEI used for the inventory presented here are more recent for several countries and thus not fully consistent to the statistics used to develop version 4 of the global irrigation map for many countries. For example, in some administrative units there is AEI in the new inventory but not in the current version of the global irrigation map. Therefore Fig. 3 should be only used to show general patterns but we will not redistribute the underlying data as part of this inventory.

The limitations and uncertainties discussed in this and the previous section indicate that the data set presented here should be used with care and by considering our assumptions that we presented in Sect. 2.2.1 and in Supplement S1. We highly recommend limiting the use of the data set for applications at the macro-scale (global or continental assessments).

\subsection{Indicators for mapping of groundwater use in irrigation}

Several studies have shown the systematic preference of farmers for groundwater whenever it is available and accessible (Shah, 2009), as it provides reliable and just in time access to water. While in theory many surface water irrigation systems should be able to provide water at lower cost than groundwater, where pumping costs may be substantial, the uncertainty and lack of predictability associated with most surface irrigation systems force farmers to seek solutions to these problems through a combination of use of groundwater and surface water. Therefore, availability of groundwater may be taken an indicator of probable or potential use of groundwater in irrigation. Such an indicator could be used to complement census-based data and provide a means of downscaling groundwater use data. The availability of groundwater resources is mainly determined by aquifer conditions (transmissivity and storage volume) and by the climatic conditions resulting in different levels of 
groundwater recharge (Fig. 5). Groundwater-based irrigation is often located in regions where both aquifer and climatic conditions are favourable, and where groundwater recharge compensates groundwater extraction (lower left panel in Fig. 5). Examples for such regions range from Bangladesh to Denmark and include the lower River Ganges plain in North India, the south-eastern part of the UK and the states of Louisiana and Florida in the south-eastern part of the USA. When climatic conditions are favourable but aquifer conditions are unfavourable, irrigation is mainly practised by using surface water. Examples include the southern part of China, the upper Mekong basin, most regions of Japan, Scandinavia (except of Denmark), the northern part of Portugal, the provinces Galicia and Asturias in north-western Spain or the north-eastern states of the USA (lower right panel in Fig. 5). When both aquifer conditions and climatic conditions are unfavourable, irrigation is only possible through diversion from rivers, reservoirs or canals supplied by water originating from regions with more favourable climate conditions (upper right panel in Fig. 5). Typical examples for those irrigation areas are Turkmenistan, Mongolia, the province of Extremadura in Spain, the coastal plains in western Chile and Peru and the largest part of Kazakhstan. When aquifer conditions are favourable but climatic conditions are unfavourable it is also necessary to import water from regions with more favourable climate conditions to ensure a sustainable use of water resources. In this case, groundwater recharge by percolation losses from canals, rivers or surface water-based irrigation can be recycled through groundwater extraction resulting in a conjunctive use of groundwater and surface water (upper left panel in Fig. 5). Examples for this type of irrigation are the Punjab province and the northern part of Sindh province in Pakistan, the state of Nevada in the USA or the irrigation areas along the river Nile in Egypt. Another option is the exploitation of deep non-renewable groundwater, resulting in a non-sustainable use of water resources like in Saudi Arabia, western Egypt and the interior of the Libyan Arab Jamahiriya (upper left panel in Fig. 5).

Although the examples presented here are in good agreement to the typology shown in Fig. 5, there are also examples that do not fit in this typology. One example are irrigation schemes located in many regions of Southeast Asia (e.g. Mekong delta or the East coast of Sumatra) or the River Po plain in northern Italy which according to the census data use surface water but according to the typology should use groundwater (lower left panel in Fig. 5). The reason is here that in these more humid regions both types of water resources, groundwater and surface water, are available and that most of these irrigation schemes were constructed a long time ago, often in large centrally planned public projects (Cleary, 2003; Smith, 1852). The pumping technology which is in use today was not available at the time of the construction of these schemes. Therefore groundwater was available but the required volumes were not accessible. Thus,

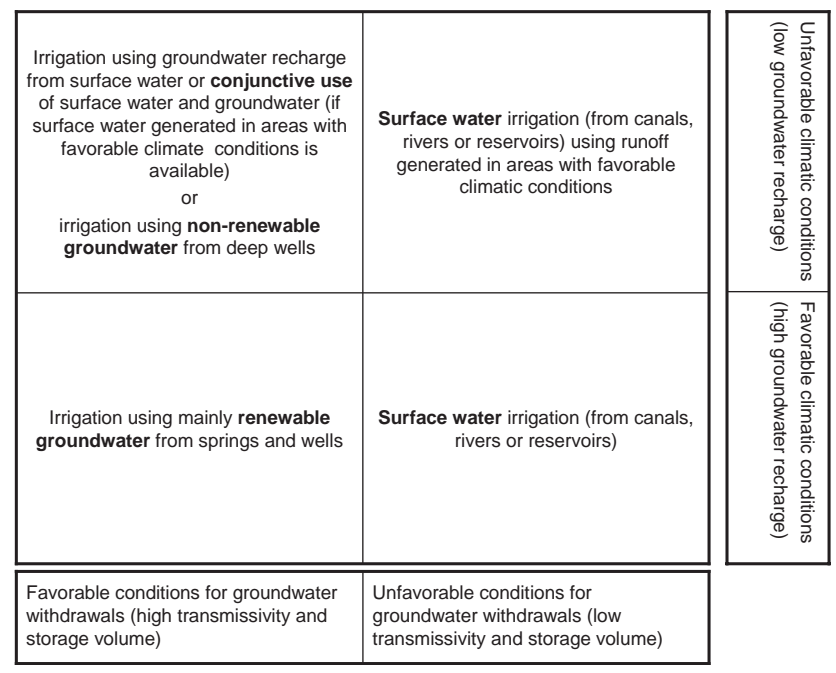

Fig. 5. General typology of groundwater and surface water resources use in irrigation dependent on climate and aquifer conditions.

the technological development adds a historical component which needs to be considered when describing changes of water sources for irrigation in time. Pumping costs and the relatively stable surface water availability may also explain the preferred use of surface water.

The preference for groundwater or surface water use is also related to tenancy, with private schemes more often irrigated with groundwater and public or state farms more often irrigated with surface water. Another factor is crop type, with vegetables often irrigated with groundwater and staple cereal crops cultivated at the large scale more often irrigated with surface water. These are dimensions that cannot be captured in a simple two-dimensional typology as that of Fig. 5.

It has been shown before that many of the areas equipped for irrigation with groundwater are located in regions of high population density (e.g. for South Asia in Shah, 2009). But this is also true for areas irrigated with surface water because irrigation is used in general to intensify agricultural production by reducing drought stress which results in higher crop yields (Siebert and Döll, 2010). Such intensification is necessary in particular in highly populated regions because of the low per cap availability of agricultural land. Therefore, in many regions the density of population is a good predictor for the density of irrigated land. However, we cannot see any reason why in regions of high population density groundwater use in irrigation should preferred to surface water use. Groundwater will not be used if it is not available or accessible independently of any population density and the same is valid for surface water as well. For example, irrigation is mainly based on surface water in the highly populated river Nile delta while in many regions in the deserts, where population density is low, mainly groundwater 
is being used for irrigation. Therefore we are convinced that the availability and accessibility of the water resource is determining to a large extent whether groundwater or surface water is being used for irrigation while population density, together with other predictors like aridity, are good indicators for the total density of irrigated land.

To test the simplified typology of Fig. 5, we intersected areas equipped for irrigation with groundwater at the 5 arcmin pixel scale (Fig. 3, top) with the continental groundwater resources maps of the World-wide Hydrogeological Mapping and Assessment Programme (WHYMAP, available at http://www.whymap.org). This map distinguishes three aquifer classes (major groundwater basins, complex hydrogeological structures and local and shallow aquifers) and five groundwater recharge classes $\left(0-2 \mathrm{~mm} \mathrm{yr}^{-1}, \quad 2-20 \mathrm{~mm} \mathrm{yr}^{-1}, \quad 20-100 \mathrm{~mm} \mathrm{yr}^{-1}\right.$, $100-300 \mathrm{~mm} \mathrm{yr}^{-1}$ and larger than $300 \mathrm{~mm} \mathrm{yr}^{-1}$ ). Although $36 \%$ of the global ice-free land was classified as major groundwater basin, $56 \%$ of total AEI and $65 \%$ of AEI_GW were located there. In contrast, $47 \%$ of the global ice-free land was classified as areas with local and shallow aquifers but only $19 \%$ of total AEI and 10\% of AEI_GW was located in these regions (Table 4). Globally averaged, the ratio of AEI_GW over AEI is 0.44 for major groundwater basins, 0.38 for areas with complex hydrogeological structure and 0.20 for areas with local and shallow aquifers. This shows the importance of favourable aquifer conditions for the establishment of irrigation infrastructure. However, the majority of surface water based irrigation is also located on aquifers favourable for groundwater extraction. Furthermore, more than $44 \%$ of the AEI_GW is located in regions with a groundwater recharge of $20-100 \mathrm{~mm} \mathrm{yr}^{-1}$, compared to $14 \%$ of the ice-free land area and $32 \%$ of total AEI located in these areas. Thus, there appears to be a preference to groundwater use under conditions of medium groundwater recharge because surface water availability in many of the areas is seasonally strongly variable. Only $1.2 \%$ of total AEI_GW and $1.7 \%$ of total AEI were located in major groundwater basins with a groundwater recharge larger than $300 \mathrm{~mm} \mathrm{yr}^{-1}$, indicating that in these areas enough rainfall is available for crop production. Considering the coarse resolution of the hydrogeological map and of the groundwater inventory (for several countries), we conclude that groundwater availability is a reasonably good predictor for the preference for groundwater use in irrigation, and that the general typology of groundwater and surface water use for irrigation (Fig. 5) is suitable.

\subsection{Comparison to other estimates and data}

Total area equipped for irrigation in this inventory is 301 million ha and therefore larger than AEI reported in version 3 of the global map of irrigation areas (Siebert et al., 2005) with 274 million ha, or version 4 of the same map (Siebert et al., 2006) with 279 million ha. This is due to an increase of irrigation extent mainly in South Asia and Southeast Asia, and to a revision in the statistics for China. The percentage of AEI irrigated with groundwater is $38 \%$ in this inventory and thus similar to the percentage estimated before in Burke (2002). The percentage of total consumptive water use for irrigation that is from groundwater is $43 \%$ in this inventory which is larger than a previous estimate of $20 \%$ of water withdrawals for irrigation stemming from groundwater (Zekster and Everett, 2004). This difference between the computed consumptive use and the reported withdrawal use may be explained, at least to some extent, by the large conveyance losses of withdrawn irrigation water by evaporation and deep percolation in irrigation canals transporting surface water to the fields (Bos and Nugteren, 1990). This results in a lower overall irrigation "efficiency" in canal irrigation as compared to groundwater which is usually withdrawn close to the location of water application (Foster and Perry, 2010). Further the consumptive fraction is in general lower in paddy fields that are flooded during a large part of the growing season since in addition to percolation losses the water needed additionally for land preparation can be returned to underlying aquifers (Guerra et al., 1998). GCWM does not account for these water requirements as consumptive water use but the water requirements are part of the irrigation water withdrawals reported in water use statistics, resulting in low consumptive fraction. Most of the irrigated paddy rice is produced in South and Southeast Asia, and is in large majority based on surface water sources. It is therefore very likely that the groundwater proportion in irrigation water use is much larger for consumptive use than for withdrawal use.

A comparison of computed ICWU_GW to annual groundwater withdrawals for irrigation reported for Federal States and Union Territories in India (Central Ground Water Board, 2006) shows a very good agreement for most of the states with an $r^{2}$ of 0.90 (Fig. 6). The annual groundwater withdrawals were computed by multiplying the average discharge and annual working hours of each structure. The annual groundwater withdrawals for irrigation should be larger than ICWU_GW because of infiltration losses estimated at about 30\% (Central Ground Water Board, 2009). However, the reported annual groundwater withdrawal for India is $213 \mathrm{~km}^{3} \mathrm{yr}^{-1}$ and thus only $4 \%$ larger than the ICWU_GW computed in this inventory $\left(204 \mathrm{~km}^{3} \mathrm{yr}^{-1}\right)$. This indicates either an underestimation of the annual groundwater withdrawals, an overestimation of infiltration losses in fields irrigated with groundwater by the Central Ground Water Board or an overestimation of the ICWU_GW computed in the inventory presented here.

ICWU_GW computed for the federal states of the USA $\left(88 \mathrm{~km}^{3} \mathrm{yr}^{-1}\right)$ is larger than the groundwater application for irrigation reported by Veneman et al. (2004) for year 2003 $\left(54 \mathrm{~km}^{3} \mathrm{yr}^{-1}\right)$ and even larger than groundwater withdrawals for irrigation reported by the United States Geological Survey (Kenny et al., 2009) for year $2005\left(75 \mathrm{~km}^{3} \mathrm{yr}^{-1}\right)$. 
Table 4. Percentage of total surface area (AS), area equipped for irrigation (AEI) and area equipped for irrigation with groundwater (AEI_GW) per WHYMAP aquifer class and groundwater recharge class.

\begin{tabular}{|c|c|c|c|c|}
\hline $\begin{array}{l}\text { WHYMAP aquifer } \\
\text { classification }\end{array}$ & $\begin{array}{l}\text { Groundwater re- } \\
\text { charge }\left(\mathrm{mm} \mathrm{yr}^{-1}\right)\end{array}$ & AS $(\%)$ & AEI $(\%)$ & AEI_GW (\%) \\
\hline Major groundwater basin & $<2$ & 6.3 & 4.4 & 3.2 \\
\hline Major groundwater basin & $2-20$ & 8.0 & 12.0 & 13.6 \\
\hline Major groundwater basin & $20-100$ & 8.0 & 20.5 & 28.9 \\
\hline Major groundwater basin & $100-300$ & 8.7 & 17.6 & 18.3 \\
\hline Major groundwater basin & $>300$ & 4.3 & 1.7 & 1.2 \\
\hline Major groundwater basin & Total & 35.5 & 56.2 & 65.0 \\
\hline $\begin{array}{l}\text { Area with complex } \\
\text { hydrogeological structure }\end{array}$ & $2-20$ & 5.8 & 5.3 & 4.4 \\
\hline $\begin{array}{l}\text { Area with complex } \\
\text { hydrogeological structure }\end{array}$ & $20-100$ & 5.7 & 11.3 & 15.0 \\
\hline $\begin{array}{l}\text { Area with complex } \\
\text { hydrogeological structure }\end{array}$ & $100-300$ & 4.9 & 7.0 & 5.0 \\
\hline $\begin{array}{l}\text { Area with complex } \\
\text { hydrogeological structure }\end{array}$ & $>300$ & 1.3 & 0.9 & 0.2 \\
\hline $\begin{array}{l}\text { Area with complex } \\
\text { hydrogeological structure }\end{array}$ & Total & 17.7 & 24.4 & 24.6 \\
\hline $\begin{array}{l}\text { Area with local and shallow } \\
\text { aquifers }\end{array}$ & $<100$ & 31.0 & 10.7 & 7.9 \\
\hline $\begin{array}{l}\text { Area with local and shallow } \\
\text { aquifers }\end{array}$ & $>100$ & 15.9 & 8.7 & 2.5 \\
\hline $\begin{array}{l}\text { Area with local and shallow } \\
\text { aquifers }\end{array}$ & Total & 46.8 & 19.4 & 10.4 \\
\hline Ice-free land & Total & 100.0 & 100.0 & 100.0 \\
\hline
\end{tabular}

There seems to be a systematic overestimation so that a correlation between computed ICWU_GW and reported groundwater application yields a relatively high correlation coefficient of 0.75 (Fig. 6). The overestimation may be related to the assumptions about the start and the length of cropping periods in GCWM. It also has been shown before that irrigation water requirements computed for the USA are very sensitive to the choice of the method for computing potential evapotranspiration (Penman-Monteith or Priestley-Taylor), and that irrigation water requirements computed in GCWM using the Priestley-Taylor method fit much better to irrigation water requirements reported in census publications. Furthermore it is assumed in GCWM that actual evpotranspiration of irrigated crops is equal to the potential evapotranspiration resulting in an overestimation of ICWU in case of deficit irrigation (Siebert and Döll, 2010). It should be noted, however, that irrigation water withdrawals and irrigation water application reported in the census publications were mostly modelled or estimated, not measured. In 2003, only $16 \%$ of the wells used for irrigation in the USA were equipped with meters (Veneman et al., 2004).
ICWU_GW was also compared to statistics on groundwater abstraction for irrigation provided by Eurostat for 18 countries being a member or candidate of the European Union (Table 5). For most of the European countries, areas actually irrigated with groundwater were derived from statistics collected for the farm structure survey 2003 and provided by Eurostat as well (see Supplement S1). Therefore, we also used, if available, water abstraction statistics for the reference year 2003 (Table 5). The comparison shows that computed ICWU_GW is larger than reported groundwater abstraction for irrigation for most of the countries. The major reason may be a discrepancy between the groundwater-based irrigated area that was assumed by Eurostat to determine groundwater abstractions and AAI_GW of this inventory (Table 5, 5th column). According to the farm structure survey 2003 (results made available at http://epp.eurostat.ec.europa.eu/portal/page/portal/ agriculture/data/ad_hoc_tables_farm_structure_survey), area irrigated with groundwater in Spain is 1.3 million ha (37\% of the total AAI), area irrigated with surface water is 0.5 million ha (15\% of the total AAI), 1.7 million ha ( $48 \%$ of the total AAI) are irrigated with water from off farm 
Table 5. Groundwater extraction for irrigation reported for European countries (Eurostat, http://nui.epp.eurostat.ec.europa.eu/nui/show.do? dataset=env_watq2_1\&lang=en, last access: 9 April 2010), area actually irrigated with groundwater (AAI_GW) and consumptive groundwater use for irrigation (ICWU_GW) as computed in this manuscript.

\begin{tabular}{|c|c|c|c|c|c|c|}
\hline \multirow[t]{4}{*}{ Country } & \multicolumn{3}{|c|}{ EUROSTAT } & \multicolumn{3}{|c|}{ This inventory } \\
\hline & \multirow{3}{*}{$\begin{array}{c}\text { Reference } \\
\text { year }\end{array}$} & \multirow{2}{*}{\multicolumn{2}{|c|}{$\begin{array}{l}\text { Groundwater abstraction } \\
\text { for irrigation }\end{array}$}} & \multirow{3}{*}{$\begin{array}{l}\text { AAI_GW } \\
(\% \text { of total } \\
\text { AAI })\end{array}$} & \multicolumn{2}{|c|}{ ICWU_GW } \\
\hline & & & & & & \\
\hline & & $\begin{array}{r}\text { (\% of total } \\
\text { water ab- } \\
\text { straction for } \\
\text { irrigation) }\end{array}$ & $\left(\mathrm{Mm}^{3} \mathrm{yr}^{-1}\right)$ & & $\begin{array}{r}(\% \text { of total } \\
\text { ICWU) }\end{array}$ & $\left(\mathrm{Mm}^{3} \mathrm{yr}^{-1}\right)$ \\
\hline Turkey & 2003 & 18.4 & 6073 & 49.3 & 50.4 & 9390 \\
\hline Portugal & 1998 & 64.0 & 4193 & 54.9 & 54.5 & 731 \\
\hline Spain & 2003 & 15.8 & 3859 & 37.1 & 39.3 & 7714 \\
\hline Greece & 2003 & 40.0 & 3413 & 48.1 & 50.5 & 3605 \\
\hline France & 2003 & 26.9 & 1482 & 44.6 & 40.4 & 1566 \\
\hline Cyprus & 2003 & 70.3 & 126 & 59.7 & 59.7 & 203 \\
\hline Germany & 2002 & 76.8 & 109 & 78.8 & 76.2 & 153 \\
\hline Austria & 1999 & 100.0 & 68 & 83.2 & 84.0 & 27 \\
\hline The Netherlands & 1999 & 76.3 & 58 & 58.0 & 54.7 & 29 \\
\hline Sweden & 2003 & 20.2 & 19 & 34.1 & 35.3 & 17 \\
\hline Hungary & 2003 & 9.9 & 17 & 22.0 & 21.7 & 68 \\
\hline Bulgaria & 2003 & 0.7 & 5 & 22.6 & 22.3 & 49 \\
\hline Macedonia & 2003 & 1.2 & 5 & 6.3 & 6.3 & 22 \\
\hline Norway & 2003 & 6.0 & 4 & 5.8 & 5.7 & 1 \\
\hline Romania & 2003 & 0.2 & 2 & 8.6 & 8.2 & 75 \\
\hline Lithuania & 2004 & 66.7 & 1 & 73.7 & 73.7 & 1 \\
\hline Slovenia & 2003 & 4.7 & $<0.5$ & 10.7 & 10.7 & $<0.5$ \\
\hline Czech Republic & 2003 & 0.5 & $<0.5$ & 6.9 & 6.3 & 1 \\
\hline
\end{tabular}

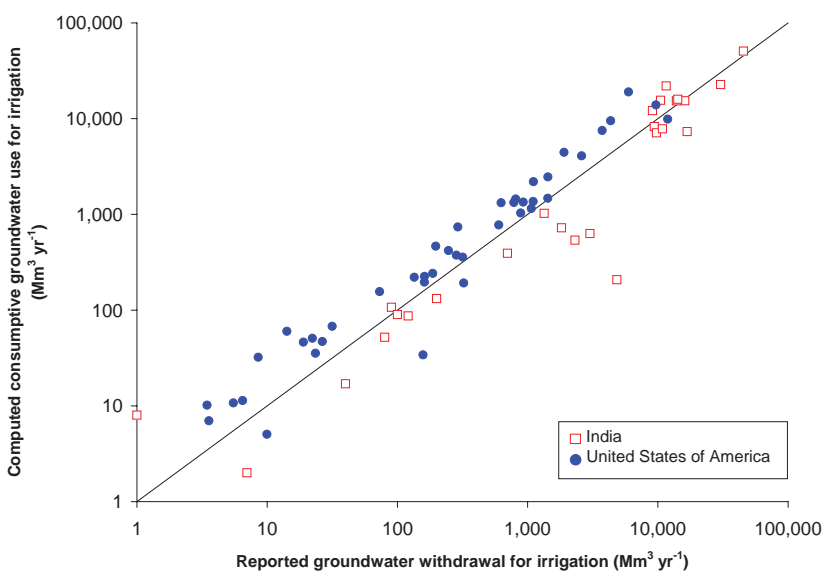

Fig. 6. Computed consumptive groundwater use for irrigation versus reported annual groundwater withdrawals for irrigation in federal states and union territories of India and irrigation water application from groundwater in federal states of the conterminous USA (data sources: Central Ground Water Board, 2006; Veneman et al., 2004). water supply networks and 8520 ha $(0.2 \%)$ are irrigated with water from mixed sources. Even when assuming that all the irrigation water provided by off farm water networks belongs to the surface water category, ICWU_GW computed by GCWM was $39 \%$ of the total ICWU and thus significantly larger than the percentage of groundwater abstraction for irrigation reported by Eurostat for Spain $(16 \%)$. For Bulgaria the water use statistics reported that only $0.7 \%$ of the total water use for irrigation was from groundwater while at the same time, according to the farm structure survey, 13980 ha (18\% of total AAI) was irrigated with groundwater and 6600 ha ( $8 \%$ of total AAI) with mixed surface and groundwater. In Portugal groundwater abstraction for irrigation as reported by Eurostat was almost six times larger than ICWU_GW computed in this inventory. The reason is that the water use statistics refer to year 1998 when total AAI was about 606000 ha while total AAI in 2003 was only 248040 ha. This shows that it is very important to consider data from similar reference years in such a comparison. 


\section{Conclusions}

A global inventory of groundwater and surface water use in irrigation has been compiled using mainly census based statistical data. Uncertainties remain on the areas equipped for irrigation with groundwater and on the related water uses either due to missing data or use of a variety of definitions for irrigated land and its water sources and conjunctive use of groundwater and surface water. Considerable data "infilling" is still required at sub-national level as indicated in Table 1 and the limitations of both the data and the methodology need to be well understood. These limitations notwithstanding, the inventory allows a comparison of irrigated areas that are supplied by groundwater and by surface water together with estimates of crop water use that can be attributed to either source. While the macro-scale patterns of groundwater use for irrigation are represented to give a refined global picture, the nature of national statistical data collection will always limit the precision at sub-national levels where irrigated areas can be matched with groundwater resources. Hence the inventory can only be recommended as a baseline for studies at the global or continental scale since it has the advantage of both global coverage and the application of standard definitions. These properties of the inventory allow regional comparisons to be made.

At national and sub-national level, the experience with the compilation of groundwater use information (such as India) leads to the conclusion that there is no substitute for national census data. What can be advocated is the application of a commonly accepted terminology and of similar definitions in relation to water use. The AQUASTAT methodology offers one standard that allows water use data in agriculture to be compiled for the point of use and that could be used as a starting point for such a standardisation.

In terms of global resource assessments, the point of interest is the relation of the groundwater withdrawals to the aquifers that furnish the resource. Here, the relationship between the distribution of irrigated land in the global map of irrigation areas and available aquifer properties has been tested and shown to require a comparable 5 arc min resolution of continental geology/hydrogeology. This requires digital continental geological/hydrogeological mapping on at a more refined scale in which properties of aquifers can be compared with the distributions of AEI. At present such digital products are not available in the public domain.

Groundwater use for irrigation is significant and increasing (comp. Fig. 4). In general it provides farmers with a reliable source of water that can be used in a flexible manner. However, in many regions, declines of the groundwater table have been reported with reductions of river base flow and associated impacts on aquatic ecosystems. This inventory offers a digital product that can be used to assess the impacts of groundwater use in relation to spatial variations in water availability to identify regions where groundwater-related problems can be expected to emerge.

\section{Supplementary material related to this article is available online at: http://www.hydrol-earth-syst-sci.net/14/1863/2010/ hess-14-1863-2010-supplement.zip.}

Acknowledgements. The authors thank Willi Struckmeier (Bundesanstalt für Geowissenschaften und Rohstoffe, Hannover, Germany) for providing us with the GIS-data layers developed by the World-wide Hydrogeological Mapping and Assessment Programme (WHYMAP), Jeremy Wilkinson (University of Frankfurt, Germany) for interesting and constructive discussions regarding data quality of statistics on groundwater use for irrigation and Pradeep Kashyap (G. B. Pant University, Hill Campus, Ranichauri, India) for insights and help regarding irrigation in India.

Edited by: H. Cloke

\section{References}

Ahmed, I. and Umar, R.: Groundwater flow modelling of YamunaKrishni interstream, a part of central Ganga Plain Uttar Pradesh, J. Earth Syst. Sci., 118(5), 507-523, 2009.

Allen, R. G., Pereira, L. S., Raes, D., and Smith, M.: Crop evapotranspiration - guidelines for computing crop water requirements, FAO Irrigation and Drainage Paper 56, FAO, Rome, Italy, 1998.

Bos, M. G. and Nugteren, J.: On irrigation efficiencies, 4th edition, International Institute for Land Reclamation and Improvement (ILRI), Wageningen, The Netherlands, 1990.

Brånvall, G., Eriksson, M., Johansson, U., Svensson, P.: Water accounts, Statistics Sweden, http://www.scb.se/statistik/ _publikationer/MI0902_2000A01_BR_MI71OP0006ENG.pdf, last access: 28 May 2010, Stockholm, Sweden, 41 pp., 1999.

Burke, J. J.: Groundwater for irrigation: productivity gains and the need to manage hydro-environmental risk, in: Intensive use of groundwater challenges and opportunities, edited by: Llamas, R. and Custodio, E., Balkema, Abingdon, UK, 478 pp. 2002.

Central Ground Water Board: Dynamic ground water resources of India (as on March 2004), Central Ground Water Board, Ministry of Water Resources, Government of India, http://cgwb. gov.in/documents/DGWR2004.pdf, last access: 9 April 2010, Faridabad, India, 126 pp., 2006.

Central Ground Water Board: Ground water resource estimation methodology. Report of the Ground Water Resource Estimation Committee, Central Ground Water Board, Ministry of Water Resources, Government of India, http://cgwb.gov.in/documents/ gec97.pdf, last access: 9 April 2010, Faridabad, India, 113 pp., 2009.

Cleary, M.: Land codes and the state in French Cochinchina c. 1900-1940, J. Hist. Geogr., 29, 356-375, doi:10.1006/jhge.2001.0465, 2003. 
Döll, P., Fiedler, K., and Zhang, J.: Global-scale analysis of river flow alterations due to water withdrawals and reservoirs, Hydrol. Earth Syst. Sci., 13, 2413-2432, doi:10.5194/hess-132413-2009, 2009.

Döll, P.: Vulnerability to the impact of climate change on renewable groundwater resources: a global-scale assessment, Environ. Res. Lett., 4, 035006, doi:10.1088/1748-9326/4/3/035006, 2009.

FAO: AQUASTAT - FAO's global information system on water and agriculture, FAO, http://www.fao.org/nr/aquastat, last access: 16 March 2010, Rome, Italy, 2010.

Federal State Statistics Service: Environment protection in Russia, 2006, Federal State Statistics Service, Moscow, Russia, 234 pp., 2006.

Federal State Statistics Service: Results of all-Russia agricultural census 2006, Vol. III: Soil resources. Federal State Statistics Service, Moscow, Russia, 311 pp., 2008.

Foster, S. S. D. and Perry, C. J.: Improving groundwater resource accounting in irrigated areas: a prerequisite for promoting sustainable use. Hydrogeol. J., 18(2), 291-294, doi:10.1007/s10040-009-0560-x, 2010.

Foster, S. and Loucks, D.P.: Non-Renewable Groundwater Resources, Series on Groundwater No. 10, UNESCO, Paris, 2006.

Giordano, M.: Agricultural groundwater use and rural livelihoods in sub-Saharan Africa: A first-cut assessment, Hydrogeol. J., 14(3), 310-318, doi:10.1007/s10040-005-0479-9, 2006.

Glickman, D., Gonzalez, M., and Donald, M. B.: Farm and Ranch Irrigation Survey (1998), 1997 census of agriculture, Volume 3, Special Studies, Part 1, National Agricultural Statistics Service (NASS), US Department of Agriculture (USDA), http://www.agcensus.usda.gov/Publications/ 1997/Farm_and_Ranch_Irrigation_Survey/fris97.pdf, last access: 9 April 2010, 1999.

Guerra, L. C., Bhuiyan, S. I., Tuong, T. P. and Barker, R.: Producing more rice with less water from irrigated systems, SWIM Paper 5, International Water Management Institute, Colombo, Sri Lanka, 1998.

Guzman-Soria, E., Hernandez-Martinez, J., Garcia-Salazar, J. A., Rebollar-Rebollar, S., de la Garza-Carranza, M. T., and Hernandez-Soto, D.: Groundwater consumption in Guanajuato, Mexico, Agrociencia, 43(7), 749-761, 2009.

INDIAAGRISTAT: Net area irrigated from different sources of irrigation and gross irrigated area in India (1950-1951 to 2005-2006), Data compiled from statistics released by Ministry of Agriculture Govt. of India, http://www.indiastat.com/table/ agriculture/2/irrigationbysource/449345/10539/data.aspx, last access: 31 May 2010, 2010.

Kenny, J. F., Barber, N. L., Hutson, S. S., Linsey, K. S., Lovelace, J. K., and Maupin, M. A.: Estimated use of water in the United States in 2005, http://pubs.usgs.gov/circ/1344/pdf/ c1344.pdf, last access: 9 April 2010, US Geological Survey Circular 1344, Reston, Virginia, USA, 52 pp., 2009.

Konikow, L. F. and Kendy, E.: Groundwater depletion: A global problem, Hydrogeol. J., 13, 317-320, doi:10.1007/s10040-0040411-8, 2005

Narayanamoorthy, A.: Trends in irrigated area in India:1950-51 to 2002-03. Presentation held at the First International Workshop on Global Irrigated Area Mapping, 25-27 September 2006, http://www.iwmigiam.org/info/main/presentations/
Day2-03-Narayanmurthi-Trends\%20in\%20Irrigated\%20Area\% 20in\%20India\%201950-51\%20to\%202002-03.pdf, last access: 31 May 2010, Colombo, Sri Lanka, 2006.

Oosterbaan, R. J.: Hydrological and environmental impacts of the irrigation improvement projects in Egypt, Nile Valley and Delta, Report of a consultancy assignment to the Egyptian-Dutch Water management Panel, ILRI, http://www.waterlog.info/pdf/irrimpr. pdf, last access: 19 March 2010, Wageningen, 51 pp., 1999.

Ozdogan, M. and Gutman, G.: A new methodology to map irrigated areas using multi-temporal MODIS and ancillary data: An application example in the continental US, Remote Sens. Environ., 112, 3520-3537, doi:10.1016/j.rse.2008.04.010, 2008.

Pervez, S., Brown, J. F., and Maxwell, S.: Evaluation of remote sensing-based irrigated area map for the conterminious United States, Proceedings of the ASPRS Pecora 17 conference, 18-20 November 2008, http://www.asprs.org/publications/ proceedings/pecora17/pecora17_proceedings/0027.pdf, last access: 19 March 2010, Denver, Colorado, USA, 2008.

Portmann, F. T., Siebert, S., and Döll, P.: MIRCA2000 - Global Monthly Irrigated and Rainfed Crop Areas around the year 2000: A new high-resolution data set for agricultural and hydrological modeling, Global Biogeochem. Cy., 24, GB1011, doi:10.1029/2008GB003435, 2010.

Rodell, M., Velicogna, I., and Famiglietti, J. S.: Satellite-based estimates of groundwater depletion in India, Nature, 460, 999-1002, doi:10.1038/nature08238, 2009.

Rost, S., Gerten, D., Bondeau, A., Lucht, W., Rohwer, J., and Schaphoff, S.: Agricultural green and blue water consumption and its influence on the global water system, Water Resour. Res., 44, W09405, doi:10.1029/2007WR006331, 2008.

Scanlon, B. R., Jolly, I., Sophocleous, M., and Zhang, L.: Global impacts of conversions from natural to agricultural ecosystems on water resources: Quantity versus quality, Water Resour. Res., 43, W03437, doi:10.1029/2006WR005486, 2007.

Shah, T.: Taming the anarchy: groundwater governance in South Asia. Resources for the Future, Washington, DC, and International Water Management Institute, Colombo, Sri Lanka, 310 pp., 2009.

Shah, T., Burke, J., and Villholth, K.: Groundwater: a global assessment of scale and significance, in: Water for Food, Water for Life, edited by: Molden, D., Earthscan, London, UK and IWMI, Colombo, Sri Lanka, 395-423, 2007.

Shiklomanov, I. A.: Appraisal and assessment of world water resources, Water Int., 25(1), 11-32, 2000.

Siebert, S. and Döll, P.: Quantifying blue and green virtual water contents in global crop production as well as potential production losses without irrigation, J. Hydrol., 384(3-4), 198-217, doi:10.1016/j.jhydrol.2009.07.031, 2010.

Siebert, S., Hoogeveen, J., and Frenken, K.: Irrigation in Africa, Europe and Latin America. Update of the Digital Global Map of Irrigation Areas to Version 4, Frankfurt Hydrology Paper 05, Institute of Physical Geography, University of Frankfurt, Frankfurt am Main, Germany, 134 pp., 2006.

Siebert, S., Döll, P., Hoogeveen, J., Faures, J.-M., Frenken, K., and Feick, S.: Development and validation of the global map of irrigation areas, Hydrol. Earth Syst. Sci., 9, 535-547, doi:10.5194/hess-9-535-2005, 2005. 
Smith, R. B.: Italian irrigation: a report on the agricultural canals of Piedmont and Lombardy, Allen and Co., London, Blackwood and Sons, Edinburgh, 434 pp., 1852.

Statistics Sweden: Water withdrawal and water use in Sweden 2005, Statistics Sweden, http://www.scb.se/statistik/MI/MI0902/ 2005A01A/MI0902_2005A01A_SM_MI27SM0701.pdf, last access: 28 May 2010, Stockholm, Sweden, 23 pp., 2007.

Thenkabail, P. S., Biradar, C. M., Noojipady, P., Dheeravath, V., Li, Y., Velpuri, M., Gumma, M., Gangalakunta, O. R. P., Turral, H., Cai, X., Vithanage, J., Schull, M. A., and Dutta, R.: Global irrigated area map (GIAM), derived from remote sensing for the end of the last millennium, Int. J. Remote Sens., 30(14), 36793733, doi:10.1080/01431160802698919, 2009.

US Department of Agriculture: Farm and Ranch Irrigation Survey (1994), 1992 census of agriculture, National Agricultural Statistics Service (NASS), http://www.agcensus.usda.gov/ Publications/1992/Farm_and_Ranch_Irrigation_Survey/index. asp, last access: 9 April 2010, 1996.

US Department of Commerce: Irrigation and Drainage, Fourteenth census of the United States 1920, Volume VII, Bureau of the Census, Government Printing Office, Washington, USA, 1922.

US Department of Commerce: Irrigation of agricultural lands, Fifteenth census of the United States 1930, Bureau of the Census, Government Printing Office, Washington, USA, 1932.

US Department of Commerce: Irrigation of agricultural lands, Sixteenth census of the United States 1940, Bureau of the Census, Government Printing Office, Washington, USA, 1942.

US Department of Commerce: Irrigation of agricultural lands, United States census of agriculture 1950, Volume III, Bureau of the Census, Government Printing Office, Washington, USA, 1952.
US Department of Commerce: United States summary and state data, United States census of agriculture 1982, Volume 1, Part 51, Bureau of the Census, Government Printing Office, Washington, USA, 1984.

Veneman, A. M., Jen, J. J., and Bosecker, R. R.: Farm and Ranch Irrigation Survey (2003), 2002 census of agriculture, Volume 3, Special Studies, Part 1, National Agricultural Statistics Service (NASS), US Department of Agriculture (USDA), http:// www.agcensus.usda.gov/Publications/2002/FRIS/fris03.pdf, last access: 9 April 2010, 2004.

Vörösmarty, C. J., Leveque, C., and Revenga, C.: Fresh water, in: Ecosystems and human well-being: current states and trends, Millenium Ecosystem Assessment, Condition and Trends Working Group, Island Press, Washington, DC, 165-207, 2005.

Wang, J., Huang, J., Rozelle, S., Huang, Q., and Zhang, L.: Understanding the water crisis in Northern China: what the government and farmers are doing, Int. J. Water Resour. D., 25(1), 141-158, doi:10.1080/07900620802517566, 2009.

Wisser, D., Frolking, S., Douglas, E. M., Fekete, B. M., Schumann, A. H., and Vörösmarty, C. J.: The significance of local water resources captured in small reservoirs for crop production - A global-scale analysis, J. Hydrol., 384, 264-275, doi:10.1016/j.jhydrol.2009.07.032, 2009.

Zektser, I. S. and Everett, L. G.: Groundwater resources of the world and their use, UNESCO IHP-VI Series on Groundwater No 6, UNESCO, Paris, France, http://unesdoc.unesco.org/ images/0013/001344/134433e.pdf, last access: 9 April 2010, 2004. 